\title{
Impact of an Inquiry-Based Science Activity about Climate Change on Development of Primary Students' Investigation Skills and Conceptual Knowledge
}

\author{
Diana Boaventura ${ }^{1,2 \star}$, Cláudia Faria ${ }^{3}$, Elsa Guilherme ${ }^{3}$ \\ ${ }^{1}$ Escola Superior de Educação João de Deus, Lisbon, PORTUGAL \\ ${ }^{2}$ MARE - Marine and Environmental Sciences Centre, University of Lisbon, Lisbon, PORTUGAL \\ ${ }^{3}$ Instituto de Educação, Universidade de Lisboa, Lisbon, PORTUGAL \\ "Corresponding Author: d.boaventura@netcabo.pt
}

Citation: Boaventura, D., Faria, C., \& Guilherme, E. (2020). Impact of an inquiry-based science learning activity about climate change effects in the ocean on the development of primary students' investigation skills and conceptual knowledge. Interdisciplinary Journal of Environmental and Science Education, 16(4), e2225. https://doi.org/ 10.29333/ijese/8554

\begin{tabular}{ll} 
ARTICLE INFO & ABSTRACT \\
\hline $\begin{array}{l}\text { Received: } \\
\text { 1 April 2020 }\end{array}$ & $\begin{array}{l}\text { Climate change is one of the major challenges facing society today and more effective education is needed } \\
\text { on this topic. This study analysed the effects of an inquiry-based science activity about climate change } \\
\text { effects in ocean ecosystems, done in a research laboratory and in the classroom, on primary students' } \\
\text { knowledge, investigation skills and satisfaction. Data were collected through the application of pretests } \\
\text { Accepted: }\end{array}$ \\
$\begin{array}{l}\text { and posttests, direct observation, questionnaires, interviews and document analysis. Results revealed } \\
\text { an increase in students' scientific knowledge and application to new situations. Regarding investigation } \\
\text { skills, all students were able to make predictions, and to easily observe and register data. However, exper- } \\
\text { imental planning and conclusions were more difficult for them. Students and teachers emphasised their } \\
\text { satisfaction with the outdoor activity, teamwork and the subject. The present study revealed a positive } \\
\text { effect of the participation in the inquiry-based activity, embedded on a socio-scientific issue, in students' } \\
\text { conceptual knowledge and in the development of investigation skills. }\end{array}$
\end{tabular}

Keywords: climate change, inquiry-based science learning, outdoor activities, ocean literacy

\section{INTRODUCTION}

Our present society is increasingly shaped and directed by science, therefore citizens need to have the knowledge, skills and disposition to make decisions and solve social-scientific problems. This requires the ability to meaningfully engage and critically reflect on science and make informed decisions (Gillies \& Rafter, 2020). Inquirybased learning in science education is broadly endorsed as an educational practice that inspires students to question the natural world, to find solutions, and develop better understandings (Gillies, Nichols, Burgh, \& Haynes, 2012), in order to respond to these society actual demands. Therefore, inquiry-based education has received much attention in educational practice and theory (see reviews in Akuma \& Callaghan, 2019; Dobber, Zwart, Tanis \& Oers, 2017; Shymansky, Kyle \& Alport, 2003; Rönnebeck, Bernholt, \& Ropohl, 2016).

Climate change is one of the major challenges facing society today and more effective education of the public on this topic is supported by several authors and organisations (e.g. Atwood-Blaine \& Bowman, 2010; Bencze, Sperling, \& Carter, 2012; UN, 2015). This need is in line with what is required in the UN 2030 Agenda for Sustainable Development (UN, 2015), which states, among other sustainable development goals (SDG), that it is crucial to "ensure inclusive and equitable quality education" (SDG 4), providing students with the knowledge and skills necessary to promote a more sustainable society, "take urgent action to combat climate change and its impacts" (SDG 13) and "conserve and sustainably use the oceans, seas and marine resources for sustainable development" (SDG14). The present study aims to analyse the learning impact of an inquiry-based science activity about the effects of climate change in the oceans, done in a research laboratory and at school, on primary students' knowledge, investigation skills and satisfaction.

Most of the previous work of inquiry-based learning

Copyright $\odot 2020$ by Author/s and Licensed by Veritas Publications Ltd., UK. This is an open access article distributed under the Creative Commons Attribution License which permits unrestricted use, distribution, and reproduction in any medium, provided the original work is properly cited. 
on climate change focused on secondary and university students (e.g. Dijkstra \& Goedhart, 2011; McCright, 2012), or on pre-service teachers and teachers approach (e.g. Namdar, 2018; Ratinen, Viiri, \& Lehesvuori, 2013). The novelty of the present study is that primary students participated in an inquiry-based science activity about climate change effects on the ocean, which involved both outdoor scientific experiments in a marine laboratory and classroom work.

The problem of this study was to analyse students' scientific knowledge about the main effects of climate change in the oceans, such as, water temperature increase, sea level rise, ice reduction, water acidification and its consequences on marine organisms; and their investigation skills like selecting the relevant information, identifying a problem, focusing on a research question, making predictions, planning experiments, observing and registering data, drawing conclusions, developing explanations and communicating findings. The main research questions were:

(1) What is the effect of the participation in an inquiry-based activity on:

- students' conceptual knowledge concerning the main effects of climate change on the oceans;

- development of students' investigation skills?

(2) How did students and teachers evaluate the inquiry-based activity, considering their satisfaction and major difficulties?

\section{Inquiry-Based Learning}

In inquiry science investigations, emphasis is placed on students' own questions, ideas, and understandings, as a constructivist practice supporting meaningful learning (National Research Council, 1996, 2013). According to the US National Research Council (1996) inquiry is:

"a multifaceted activity that involves making observations; posing questions; examining books and other sources of information to see what is already known; planning investigations; reviewing what is already known in light of experimental evidence; using tools to gather, analyse, and interpret data; proposing answers, explanations, and predictions; and communicating the results." (p. 23)

Increasing evidence demonstrates the benefits of inquiry-based science learning. There is no doubt that children are more motivated and interested to learn when they are active participants in the learning process, investigating problems that challenge their curiosity, and thinking creatively as they work towards commonly agreed conclusions (Gillies et al., 2012). One important aspect of scientific inquiry is that it links knowledge and process skills (Cremin, Glauert, Craft, Compton \& Stylianidou, 2015). When students have opportunities to engage in scientific inquiry, they increase their conceptual understanding of scientific content, as well as, their understanding of how to do science (Gillies \& Nichols, 2015). Student investigations and hands-on science activities also have the potential to enhance students' higher order learning skills, such as metacognition and argumentation (Cremin et al., 2015). In summary, student investigations and hands-on activities have the "potential to enhance students' conceptual and procedural understanding, their practical and intellectual skills, and their understanding of the nature of science" (Hofstein, Kipnis, \& Kind, 2008, p. 59 ), in addition to develop students' motivation and positive attitudes toward science (Areepattamannil, 2012).

There are also some evidence supporting the idea that the implementation of inquiry activities with younger students also plays an important role in their engagement in science (e.g. Alake-Tuenter, Biemans, Tobi, \& Mulder, 2013; Gillies \& Nichols, 2015; Löfgren, Schoultz, Hultman \& Björklund, 2013). Despite the general agreement of the importance of scientific inquiry in science education, documented by a huge body of research and reviews (e.g. Akuma \& Callaghan, 2019; Dobber et al., 2017; Shymansky et al., 2003), two main dimensions can be distinguished from conceptualisations of scientific inquiry found in the literature: the type and range of activities that students engage in, and the degree of guidance provided by the teacher (Rönnebeck et al., 2016). There are several levels of openness in the way to do inquiry, from confirmation inquiry, structured inquiry, guided inquiry, up to open inquiry (Banchi \& Bell, 2008). Here we analyse students' performance on structured and guided inquiry activities that were done at the classroom and in a research laboratory under researchers and teachers supervision.

In accordance with the need, already highlighted by Holbrook (2010), of science education to relocate from a content-led teaching direction to one that focusses on the needs and motivations of students for learning through science, the inquiry-based science methodology, aims to engage students in investigative activities on socially and environmental relevant problems, in order to develop skills of problem identification, research planning and development, data collection and analysis, and problem solving. These skills, associated with the knowledge of the nature of the scientific enterprise and its interactions with technology, society and the environment, are decisive for the construction of a scientific literacy, indispensable to the exercise of critical citizenship in the context of 
environmental scientific controversies.

Bencze et al. (2012) defend that education on climate change needs to be oriented towards encouraging and enabling students to become citizen activists, ready and willing to take personal and social actions to reduce risks associated with this issue.

The United Nations 2030 agenda for sustainable development (UN, 2015) goals includes taking urgent action to combat climate change and its impacts and improving education, awareness-raising and human and institutional capacity on climate change mitigation, adaptation, impact reduction and early warning.

The approval of a Sustainable Development Goal (SDG) on the ocean to "conserve and sustainably use the oceans, seas, and marine resources" was a major achievement for the global ocean community, but a successful implementation of this SDG 14 will require a shift in lifestyles and a transformation of the way of thinking and acting. Therefore, education systems must also react to this compelling need by defining relevant learning objectives and content and by introducing ocean pedagogies that empower learners (Santoro, Santin, Scowcroft, Fauville, \& Tuddenham, 2017). As emphasised by Brennan, Ashley and Molloy (2019), ocean literacy includes several aspects, from knowledge about how the oceans work and our impact on them, to attitudes toward topics such as sustainable development.

In this educational demand it is fundamental to promote ocean literacy at early ages, starting right from the first years of schooling, adding ocean literacy topics in the curricula (Mogias, et al., 2019; Stefanelli-Silva, Pardo, Paixão, \& Costa, 2019), such as, effects of climate change in the oceans.

\section{METHOD}

A mixed-methods design involving pretest, posttest, worksheet responses, interviews, questionnaires and direct observations was used to document the impact of the climate change inquiry unit on students' conceptual understanding, investigative skills development and evaluation of the activity.

\section{Participants}

The participants were 96 students from two primary schools of Portugal, two classes per school and the four respective schoolteachers. All students were at the fourth grade, with 9 or 10 years old. Gender distribution was 54 females and 42 males. In general students came from a good socio-cultural-economic background.

\section{Description of the Inquiry-Based Science Activity \\ Contextualizing session in the classroom. Prior to the}

visit to laboratory students read a child literature book of SpongeBob collection (Reisner \& Reed, 2011), entitled "Sponge Bob - An ecological adventure", about the effects of climate change in the ocean. The teachers conducted this moment, which aimed to motivate the students for the subsequent activities, leading them to investigate possible impacts of climate change in the oceans and to raise questions about this socio-scientific issue, thus establishing problem focus: What are the impacts of global warming on the oceans?

To answer to this major question students were involved, in the laboratory, in three experimental activities, related to several aspects of climate change effects on oceans, namely on seawater warming, on polar ice melting and on ocean acidification.

Once in the laboratory, the students were divided in three groups from nine to eleven elements and each group performed one of three possible experiments.

Experiment 1 - Effect of climate change on ocean temperature. The students were driven to an initial problem and question: What happens in the ocean as atmosphere temperature increases due to global warming?

Students had to make predictions and to compare the effects of warming two balloons, one filled with air and the other filled with sea water. They measured and compared the temperature of the seawater, which was previously inside the balloon, with the temperature of tap water, that is expected to be lower. They also registered the time that both balloons take until they burst. After understanding the experiment model and what happens to the temperature of ocean waters due to global warming, students were invited to think on the effects of ocean warming on marine organisms' distribution. This was done through an extension activity where they had to read news, about changes in geographical range of a mussel species, and discuss them with their colleagues (http://www.ccmar. ualg.pt/index.php?id=1384).

\section{Experiment 2 - Effects of climate change on polar ice} melting. This experiment analysed the effects of climate change on polar ice melting. The driving question for students was: Can seawater refreeze after melting?

In this activity, students were asked to plan and design an experiment that could answer their initial hypotheses. They should do an experiment, which enabled the comparison of the different responses of freezing a glass with salted and unsalted water, for a given period ( 30 to $60 \mathrm{~min})$. The students would observe that salty water did not freeze again, at the used temperature, and relate this evidence to the sea level rise. To conclude the activity, students had to read news about the consequences of sea 
level rise in the small island nations of the Pacific Ocean, vulnerable to the impacts of climate change (http://opiniaoenoticia.com.br/brasil/politica/ilhas-kiribati-a-primeira-vitima-do-aquecimento-global/).

Experiment 3 - Impact of climate change ocean acidification on marine organisms. This experiment analysed the indirect effects of climate change on ocean acidification, particularly the effects on mollusc shells. At the beginning of this experiment, it was discussed with students how the raise of $\mathrm{CO}_{2}$ in the atmosphere and its dissolution in sea water could cause ocean acidification, so that they could understand this process as a consequence of the climate change. The driving question was: What is the effect of the acid on shells?

Students analysed this question through changes in shell contour and weight, comparing shells placed in vinegar to shells placed in sea water. Throughout the experiment, they had to measure $\mathrm{pH}$ of seawater and vinegar, weight the shells and draw their contour in the beginning and at the end of the experiment (see Boaventura, Guilherme \& Faria, 2016 for details of this experiment). Students should conclude that acidification directly harms many of the shell forming organisms. Consequently, other direct and indirect impacts can occur both in marine food webs and in availability of food sources for humans.

The informal scientist leader draw the students' attention to the fact that some of the materials used were only a representation of the reality under analysis (lighter; vinegar) and could not present all the properties of the real materials. It was intended that students were aware of the aspects involved in an experimental activity, namely the need for accurate data recording throughout the process and the need to always have a control situation (air balloon, salt water, water without vinegar).

Intervention task back at the classroom. Students had one-month period to research and prepare a proposal, meant to raise public awareness, about one of the three issues they tested in the laboratory. This was a student-guided activity done in small groups both in the classroom, under teacher supervision, and at home. Finally, each group of students had to present and communicate to their colleagues their proposal in a one-hour session.

To accomplish this last task (which could serve as an integration of all the others) it was suggested the creation of jig saw cooperative learning, in which each group is dedicated to addressing only one of the dimensions under analysis in a first phase. Subsequently, each group is disbanded and each element integrated, together with an element from each of the other 2 groups, in a new group that elaborate the proposal to raise awareness about the problem under analysis.

Throughout the activity, students had the opportunity to identify a problem, focus on a research question, predict, observe, to draw conclusions, to generate new hypotheses, and to design an experiment (experiment 2). Additionally, they discussed the characteristics of scientific experiments such as the role of control procedures. Experiments 1 and 2 had extension activities, in which students should apply the previous learned concepts in a broader context. Finally, they had to communicate results to the class. Scientists and teachers were always available for any further clarification, seeking to ensure correct appropriation of content by students.

\section{Data Collection}

Data was collected using five instruments: application of pretests and posttests to students ( $n=79)$, observation of student activities, questionnaires to students ( $n=93$ ), interviews to students $(n=12)$ and to teachers $(n=4)$; and document analysis (e.g. students' worksheets, $n=96$; student's group proposals in the intervention task, $n=12$ ). These instruments were applied in all schools and classes. Although 96 students participated in the activities, some of them didn't answered the questionnaire, or pre and posttest, because they missed class that day.

In order to assess students previous conceptual knowledge about the scientific theme under consideration, a pretest was applied to students before the beginning of the activity. The same test was applied after the experiments implementation (posttest). These tests included 5 questions (including figures and graphics) in order to assess students learning about the effects of climate change on the ocean explored in each experiment (temperature, polar ice melting and ocean acidification):

Question 1 - After analysing the figure (illustrating $\mathrm{CO}_{2}$ trades between atmosphere and the ocean and consequent water acidification), what do you think that will happen to the ocean organisms if the water becomes more acid, due to the excess of carbon dioxide in the atmosphere?

Question 2 - What will be the consequences of ice reduction for the organisms (examples: polar bear, seals) which inhabit the Artic?

Question 3 - Looking at the photos (taken in different years: $1899,1941,2003,2004)$ what do you think that has happened in the last years that can explain the sharp reduction of ice in Muir Glacier (Alaska)?

Question 4 - Based on information provided in the graphs (about average temperature range of the ocean surface and the average seawater level over the years) what will be the relation between the increase in water 
temperature and the sea level rise? Why?

Question 5 - What are the effects of the increase of water temperature in marine organisms?

To assess the impact of the activity on students' investigation skills development, for all the experiments done in the laboratory, students' had to answer to a written worksheet involving all research steps performed during the task: introduction, problem question, predictions, material, procedure, results, and conclusions. Classroom activities were also observed in order to analyse students' involvement in the development of the intervention proposal and its presentation to the class.

Finally, to understand how students and teachers evaluated the activity, interviews were done to both participants, at the end of the activities, to get a deeper understanding about the aspects they considered important for their involvement. Student's interviews were done in pairs or groups. These interviews were semi-structured and aimed to get information on: the relevance and importance of the tasks, the learning promoted by the activity, the innovative aspects and the major difficulties felt. The interviews to teachers aimed to obtain information on: their critical appreciation of the activity (curriculum adequacy, age of students), the implementation process (expectations, difficulties, alterations made, positive aspects, recommendations), the impacts of the activity on students' learning and skills development, and student's reactions (involvement, satisfaction, learning), implications on teaching, and future perspectives (activities reutilisation).

One closed questionnaire was also applied to students, in order to assess their overall opinion about the activity and to understand which tasks they found more difficult. These questionnaires had 49 items, grouped in the following themes: general appreciation of the activity (popularity of the activity, preferred aspects, and difficulties in the activity development), and contribution to science learning (aspects related to conceptual and procedural learning). Students chose the sentences (items) they agreed with. For teachers, a written reflection was applied to assess information on how they analysed the implemented learning sequence, their major difficulties, and general appreciation of the activity.

All used instruments for data collection were developed by the authors for the evaluation of the activities created under the project 'Between tide marks: Integrating literacies (iLit)' (PTDC/CPE-CED/117923/2010), aimed to support in-service teachers to adopt inquiry-based science learning at basic education. The questionnaire was previously tested with a different class of students of the same age in order to verify if the questions were suited to the age of the participants. Data collected using the different methods were crossed to assure the reliability of the analysis and to get a deeper understanding of the activity effects.

\section{Data Analysis}

For the assessment of students' conceptual knowledge concerning the main effects of climate change on the oceans, before and after their involvement in the inquiry activity. The pretests and posttests were analysed according to the percentage of answers that were included in the following categories: incorrect answer, correct answer, no answer. The correction criteria encompassed the use of appropriate scientific language and the number of topics mentioned by the students (consequences or effects, etc.). Only the cases with both pretest and posttest per student were considered for analyses in this study. Therefore, only 79 correspondent tests were analysed. A chi-square test of independency was used for comparing the frequencies of the different categories considered (incorrect, correct and no answer) between pretest and posttest in each question.

In what concerns the development of students' investigation skills, students' worksheets were analysed in order to see their performance in the various stages of the inquiry-based activity, namely, questioning, predicting, planning, observing, data recording, concluding and performing the extension applied tasks.

Finally, to understand students' opinion about the activity, the percentage of concordance with each item (sentence) present in the closed questionnaire, was analysed. The data obtained through the questionnaires was enriched with the analysis of students' interviews that enabled to get a deeper insight on their appreciation of the activities and its major positive and negative aspects. Concerning teachers' opinion, both the written reflexion and the interview were subject to content analysis, to understand their appreciation of the activity. All written documents were subjected to content analyses based on information obtained from data and from theoretical references.

As for the intervention proposals done in the classroom, the major aspects considered were: creativity, precision and accuracy of the information within the theme, use of scientific language, interaction and discussion with the colleagues, and poster format and appearance. These aspects were analysed as insufficient, sufficient or good. Non-participant observation of the classroom activity of posters presentation allowed complementing this analysis, concerning the communication skills, thorough the analysis of the type of interaction among students. 


\section{RESULTS}

Impacts on Students' Learning and Investigation Skills' Development

Results of the pretests and posttests applied to students $(n=79)$ revealed that the number of students that did not answer to the questions reduced notably from the pretest to the posttest (Table1). The knowledge and scientific language improved in most of the questions, according to the used correction criteria.

Chi-square test results (Table 2) showed that, there was a larger number of correct answers, than what would be expected in a random distribution, in posttest, except in question 4 in which students had to analyse data in graphic format. The themes where an increase in students' knowledge (i.e. with a larger number of correct answers) was more evident were those related to the impact of glacier reduction and to the increase of water temperature on marine organisms (questions 2 and 5).

The result of the analysis of frequency and percentage of correct answers in students' worksheets, in several stages of the inquiry-based activity, is presented in Table 3. All students were able to make predictions in each activity but the activity where their initial conceptions were more distant to the scientific concept was experiment 3, "the ocean acidification". Only $21.9 \%$ of the students could make a correct experimental plan (experiment 2). Data recording and observations was one of the easiest tasks for students, presenting high percentage values in all experiments. Conclusions were difficult for students, as they also admitted in questionnaires, with percentage values below $37.5 \%$ in all tasks, with the exception of question 2 , in experiment 1 , where students had to understand the model used in the experiment and to relate each used material to the correspondent item in nature. Application

Table 1. Pre and Post- test results for each question. Frequencies and percentages of answers according to correction criteria $(\mathrm{n}=79)$

\begin{tabular}{|c|c|c|c|c|c|}
\hline \multirow[t]{2}{*}{ Question } & \multirow[t]{2}{*}{ Criteria of correction } & \multicolumn{2}{|l|}{ Pre test } & \multicolumn{2}{|l|}{ Post test } \\
\hline & & Frequency & Percentage & Frequency & Percentage \\
\hline \multirow[t]{3}{*}{1} & Incorrect answer & 14 & 17.7 & 3 & 3.8 \\
\hline & Correct answer & 63 & 79.7 & 76 & 96.2 \\
\hline & No answer & 2 & 2.5 & 0 & 0 \\
\hline \multirow[t]{3}{*}{2} & Incorrect answer & 22 & 27.8 & 9 & 11.4 \\
\hline & Correct answer & 46 & 58.2 & 68 & 86.1 \\
\hline & No answer & 11 & 13.9 & 2 & 2.5 \\
\hline \multirow[t]{3}{*}{3} & Incorrect answer & 28 & 35.4 & 30 & 38.0 \\
\hline & Correct answer & 37 & 46.8 & 47 & 59.5 \\
\hline & No answer & 14 & 17.7 & 2 & 2.5 \\
\hline \multirow[t]{3}{*}{4} & Incorrect answer & 25 & 31.6 & 36 & 45.6 \\
\hline & Correct answer & 24 & 30.4 & 20 & 25.3 \\
\hline & No answer & 30 & 38.0 & 23 & 29.1 \\
\hline \multirow[t]{3}{*}{5} & Incorrect answer & 30 & 38.0 & 24 & 30.4 \\
\hline & Correct answer & 23 & 29.1 & 47 & 59.5 \\
\hline & No answer & 26 & 32.9 & 8 & 10.1 \\
\hline
\end{tabular}

Table 2. Results of the Pearson Chi-Square Tests

\begin{tabular}{llll}
\hline Question & $\mathrm{X}^{2}(\mathrm{df}=2)$ & $\mathrm{p}$ & \\
\hline 1 & 10.33 & 0.006 & Decrease in category "incorrect" \\
2 & 15.93 & 0.000 & Decrease in categories "incorrect" and "no answer" and increase in "correct" \\
3 & 10.26 & 0.006 & Decrease in category "no answer" \\
4 & 3.27 & 0.200 & No significant changes \\
5 & 18.43 & 0.000 & Decrease in category "No answer" and increase in "correct" \\
\hline
\end{tabular}


Table 3. Frequency and percentage of correct answers in several stages of the experimental tasks

\begin{tabular}{|c|c|c|c|c|c|c|}
\hline \multirow[t]{2}{*}{ IBSL activity } & \multicolumn{2}{|c|}{ Experiment $1(n=31)$} & \multicolumn{2}{|c|}{ Experiment $2(n=32)$} & \multicolumn{2}{|c|}{ Experiment $3(n=33)$} \\
\hline & Freq. & Percentage & Freq. & Percentage & Freq. & Percentage \\
\hline Predictions & 28 & 90.3 & 20 & 62.5 & 2 & 6.1 \\
\hline Planning & ------ & ------------- & 7 & 21.9 & ------ & ------------- \\
\hline Observations & 22 & 70.9 & 27 & 84.4 & 33 & 100 \\
\hline \multicolumn{7}{|l|}{ Conclusions } \\
\hline Question 1 & 2 & 6.5 & 12 & 37.5 & 7 & 21.2 \\
\hline Question 2 & 28.8 & 92.8 & ------ & ------------- & 8 & 24.2 \\
\hline \multicolumn{7}{|l|}{$\begin{array}{l}\text { Application } \\
\text { Questions }\end{array}$} \\
\hline & 14 & 45.2 & 22 & 67.7 & ------ & ------------- \\
\hline
\end{tabular}

questions had percentages of correct answers between $45.2 \%$ and $67.7 \%$.

As for the tasks done in the classroom, the aspects that stand out most were the use of scientific language, creativity and precision/accuracy of the information, where the percentage of students with good results were, respectively, $100 \%, 34.4 \%$ and $32.3 \%$. The percentage of an adequate posters format (17.7\%) and the interaction or discussion with the colleagues (18.8\%) was considerably lower. The analysis of the presentation performance for each group also revealed that the presentation of the posters was mainly based on reading information, without any interaction with the colleagues.

All proposals had references to environmental conservation. Several groups proposed mitigating procedures for the reduction of global warming. These procedures encompassed reduction of fossil fuels use, encouragement of recycling, the use of renewable energy sources, installation of greenhouse gas emissions regulatory systems in industries, recovery of methane gas in sanitary landfills, energy saving, avoidance of deforestation and forest fires. Another group presented a scientific study on ocean acidification reduction conducted by a research institution.

During interviews students $(n=4)$ gave examples of some new concepts that they have learned:

"We learned that we should not use the car so that we don't pollute the environment with $\mathrm{CO} 2 . "$

"With $\mathrm{CO} 2$ pollution the Earth gets warmer and the glaciers will melt...the sea water level can rise and cause floods...floods in islands and coastal areas."

"Global warming increases the ocean temperature and this can be bad for the species living there."

"With ocean acidification the shells can be destroyed and some species can die."

"The more we pollute the Earth the warmer it will be, as a greenhouse effect."

"If the glaciers melt they will not freeze again after mixing with salt water."

\section{Students' Evaluation of the Activity}

Questionnaire analysis ( $n=93$ ) showed that $93.5 \%$ of the students liked to participate in the activity, although $10.8 \%$ considered it difficult. The aspects they liked most were: team work $(78.5 \%)$ and the visit to the marine laboratory (72\%), followed by the use of scientific equipment and laboratory materials (58.1\%), 'have to use the knowledge that I have from science' $(53.8 \%)$ and 'have to present my results' (51.6\%).

Most of these aspects were also mentioned in the interviews ( $n=12$ ). When asked about what they liked most in the activity they said:

"Working in a group."

"Making experiments in the laboratory."

"Research in the web."

"Learning about this theme."

The major difficulties mentioned by the students in the questionnaires were: to draw conclusions (39.8\%), to make decisions (38.7\%), to have to identify a problem 
(37.6\%), and to organize their work (36.6\%). Interestingly, the students considered that after doing the activities 'they could understand the science concepts' (81.7\%), but only $28 \%$ considered that they learned 'how to do science'. The aspects they referred as contributing for their learning were again the team work (64.5\%) and the visit to the marine laboratory (61.3\%). However, they also mentioned other aspects, such as, the help of colleagues $(58.1 \%)$ and of the teacher (47.3\%), to use the knowledge they have from science $(46.2 \%)$ and have to draw conclusions (46.2\%).

In the interviews some students $(n=4)$ referred that they did not like that: "other students didn't respect our opinion."

\section{Teachers' Evaluation of the Activity}

All teachers $(n=4)$ enjoyed to be involved in the activity and said that their students liked particularly the visit to laboratory and to conduct the experiments there, enlightening the students' involvement and satisfaction with the activity. Concerning the adequacy to curriculum and age of the students the teachers' opinions diverged. Two teachers said that "The activity was well adapted both to curriculum and age of the students". In contrast, the other two considered that the activity could be better adapted to curriculum and age of the students. One of them said that: "...the theme was difficult and would be better for older students."

Positive aspects of the activity implementation mentioned by the teachers included the interest of the theme and the use of a contextualizing session in the classroom, through the reading of a child literature book:

"Interest of the theme, using a story as an introduction to the project..."

"Awareness to this theme, and to its ecological consequences."

"It is always useful to go deep further in this theme."

Other aspects recognised by teachers on the implementation of the activity was the importance of the collaboration with a research institution "making a visit to a research laboratory", and the active role that students had in the laboratory and classroom: "Students implication in the activities, participation, cooperation and team work and communication development."

The teachers also referred to the learning skills and advantages of the activity particularly in autonomous investigation, work planning, and as introduction to new scientific concepts:
"The students had to investigate and to organize their work."

"New concepts and themes were analysed".

Despite the increase in knowledge and scientific language, the teachers still stressed out that major difficulties were related to the selection of information during investigation and some of the vocabulary which was new to the students:

"Some students had difficulties in understanding the vocabulary used in the activity."

\section{"Selection of collected information was sometimes difficult"}

For future use of the activity teachers recommended the addition of a digital image and audio support to the initial story, the publication of the students' work in the school journal and the realization of a science week to develop students' interest in this area. As for implications on teaching, they considered important to be complement learning with concepts about climate change.

\section{DISCUSSION}

The present study revealed a positive impact on students' scientific learning, shown by the progress in the ideas and explanations regarding the effects of climate change in the oceans, which resulted in a significant increase in conceptual knowledge across students. Moreover, the students were perfectly capable of applying the acquired knowledge to new situations, as revealed by the analysis of the application questions of the experimental tasks. So, in consonance with Varma (2014), this study reinforces the idea that young students can benefit from science instruction centred on inquiry-based science experimentation activities for developing a better understanding about new scientific information. It also enhances the importance of presenting complex scientific information in authentic contexts and of providing the necessary support for meaningful scientific inquiry and experimentation.

In addition to knowledge acquisition, this study aimed also to promote a development of students' inquiry skills. It is commonly accepted that inquiry should incorporate elements of observation, questioning, problem-solving, devising and conducting investigations, critical thinking, collaborative work, interpreting results, drawing conclusions and communicating findings (see Hume \& Coll, 2010). Considering these various stages of the inquiry activities, the present study revealed that all students involved were 
able to make predictions in each experiment, and to easily observe and register data. On contrary, the experimental planning was a more challenging activity and the drawing of a conclusion was a difficult task for them. Curiously, on students' evaluation of the activity, this task, 'have to draw conclusions', was simultaneously considered difficult, but also as contributing for their learning, meaning that the children enjoyed the challenge they were given.

Both students and teachers enjoyed to be involved in the activity, particularly emphasizing the visit to the laboratory and to conduct the experiments there. The visit to the laboratory had the advantage of getting in contact with a research institution, as well as, to perform more authentic scientific experiences. This type of visits can also encompass cognitive, affective and interpersonal or social impacts on students (Rickinson et al., 2004), as demonstrated by students evaluation of the process in this research. On the other hand, the contact with researchers can remove traditional stereotypes on scientists and may influence students' ideas about scientists (Boaventura, Faria, Chagas \& Galvão, 2013) and the attractiveness to work in science in a positive way (Dijkstra \& Goedhart, 2011).

Finally, the notion of authenticity and the active role of students in the activities, advocated by several authors (Dijkstra \& Goedhart, 2011; Gillies et al., 2012; Morrison, 2013), certainly contributed to the impact on students of the activity implemented in this study. According to Gillies et al. (2012) children are more motivated to learn when they are encouraged to be active participants in the learning process, investigate problems that challenge their curiosity, and think creatively as they work towards commonly agreed conclusions. The authentic process of inquiry not only leads to the development of personal conceptual understanding, but also to the development of procedural knowledge and skills and a tentative appreciation of the nature of science (Milne, 2010).

Other important aspect of the activity mentioned by the students was team work. Indeed, students showed enthusiasm and motivation for working with their colleagues in these science activities, both in the laboratory and in the classroom. According to Murphy, Varley, and Veale (2012), working in-groups can provide children with opportunities to develop their collaborative skills in solving problems and conducting investigations.

\section{CONCLUSIONS}

Ratinen et al. (2013) consider climate change a challenge to environmental educators and researchers because it is an issue that is characterized by controversy, uncertainty, interdisciplinary and complexity. Learners must be made aware not only of its causes and predicted effects but also the uncertainty of climate change and its economic, political and social dimensions. In this study, the theme of the effects of climate change on the oceans was used both as a 'real-life' situation and as an appealing learning context. This theme seemed to have contributed to students' engagement and some groups were able to propose viable solutions, during the intervention task. The present study revealed a positive impact of the inquiry-based learning activity on students' conceptual knowledge and on the development of some investigation skills. Students and teachers evaluated positively the activity, particularly the fact that it involved the development of experiments in a laboratory.

\section{IMPLICATIONS}

This study reveals that the combination of inquiry-based learning and authentic scientific contexts can have positive results on knowledge, skills and students' engagement, pointing to the need to create and implement innovative curricular resources, that promote students' engagement with science, and, at the same time, that are easily accessed and appropriated by teachers, and so, also implemented in the classroom.

However, several studies focused on curriculum innovation highlight the difficulty to change teachers' practices (e.g. Fullan, 2008; Hargreaves, 2008; Osborne \& Dillon, 2008). Indeed, besides the importance for science teachers to have access to innovative curricular resources, based on inquiry strategies and students' centred, it is also crucial for them, as suggested by Murphy et al. (2012), to have the confidence and competence to develop and implement, for themselves, more innovative inquiry-based approaches outlined in the primary curriculum. Probably, in order to promote change on teachers' practices and perspectives by empowering them to deal with barriers to innovation, it is essential to create relational spaces including science teachers and teacher educators, where teachers can exchange ideas and experiences and find theoretical explanations to justify their practices.

\section{REFERENCES}

Akuma, F. V. \& Ronel Callaghan, R. (2019). A systematic review characterizing and clarifying intrinsic teaching challenges linked to inquiry-based practical work. Journal of Research in Science Teaching. 56, 619-648. doi: 10.1002/tea.21516

Alake-Tuenter, E., Biemans, H. J. A., Tobi, H., \& Mulder, M. (2013). Inquiry-based science teaching competence of primary school teachers: A Delphi study. Teaching and Teacher Education, 35, 13-24. doi:10.1016/j.tate.2013.04.013

Areepattamannil, S. (2012). Effects of inquiry-based science instruction on science achievement and interest in science: evidence from Qatar. The Journal of Educational Research, 105 (2), 134-146. doi: 10.1080/00220671.2010.533717 
Atwood-Blaine, D., \& Bowman, R. (2010). Improving K-12 climate science education through collaborations with scientists. Geoscience and Remote Sensing Symposium (IGARSS), 2010 IEEE International, 94-97.

Banchi, H. \& Bell, R. (2008). The many levels of inquiry. Science and Children, 46 (2), 26-29.

Bencze. L., Sperling, E., \& Carter, L. (2012). Students' research-informed socio-scientific Activism: Re/Visions for a Sustainable Future. Research in Science Education, 42, 129148. doi: 10.1007/s11165-011-9260-3

Boaventura, D., Faria, C., Chagas, I., \& Galvão, C. (2013). Promoting science outdoor activities for elementary school children: Contributions from a research laboratory. International Journal of Science Education, 35 (5), 796-814.

Boaventura, D., Guilherme, E., \& Faria, C. (2016). An inquiry-based science activity centred on the effects of climate change on ocean ecosystems. School Science Review, 98 (363), 88-93.

Brennan, C., Ashley, M., \& Molloy, O. (2019). A system dynamics approach to increasing ocean literacy. Frontiers in Marine Science, 6: 360. doi: 10.3389/fmars.2019.00360

Cremin, T., Glauert, E., Craft, A., Compton, A., \& Stylianidou, F. (2015). Creative little scientists: exploring pedagogical synergies between inquiry-based and creative approaches in early years science. Education 3-13, 43 (4), 404-419. doi:

10.1080/03004279.2015.1020655

Dijkstra, E., \& Goedhart, M. (2011). Evaluation of authentic science projects on climate change in secondary schools: a focus on gender differences. Research in Science \& Technological Education, 29 (2), 131-146. doi: 10.1080/02635143.2011.581631

Dobber, M., Zwart, R., Tanis, M., \& Oers, B. (2017). Literature review: The role of the teacher in inquiry-based education. Educational Research Review, 22. 194-214. doi:10.1016/j. edurev.2017.09.002

Fullan, M. (2008). The six secrets of change. San Francisco: Jossey-Bass.

Gillies, R. M., Nichols, K., Burgh, G., \& Haynes, M. (2012). The effects of two strategic and meta-cognitive questioning approaches on children's explanatory behaviour, problem-solving, and learning during cooperative, inquiry-based science. International Journal of Educational Research, 53, 93-106. doi:10.1016/j.ijer.2012.02.003

Gillies, R. M., \& Nichols, K. (2015). How to support primary teachers' implementation of inquiry: teachers' reflections on teaching cooperative inquiry-based science. Research in Science Education, 45, 171-191. doi: 10.1007/s11165-0149418-x

Gillies, R. M., \& Rafter, M. (2020). Using visual, embodied, and language representations to teach the $5 \mathrm{E}$ instructional model of inquiry science. Teaching and Teacher Education, 87, 1-9. doi:10.1016/j.tate.2019.102951

Hargreaves, A. (2008). Mudança educativa e crise do profissionalismo [Educational change and crisis of professionalism]. In Goodson (Ed.), Formação de professores. Conhecimento e vida profissional [Teacher training. Knowledge and professional life] (pp. 209-221). Porto: Porto Editora.

Hofstein, A., Kipnis, M., \& Kind, P. (2008). Learning in and from science laboratories: Enhancing students' metacognition and argumentation skills. In C. L. Petroselli (Ed.), Science education issues and developments (pp. 59-94). New York: Nova Science.

Holbrook, J. (2010). Education through science as a motivational innovation for science education for all. Science Education International, 21, (2), 80-91

Hume, A., \& Coll, R. (2010). Authentic student inquiry: the mismatch between the intended curriculum and the student-experienced curriculum. Research in Science \& Technological Education, 28 (1), 43-62. doi: 10.1080/02635140903513565

Löfgren, R., Schoultz, J., Hultman, G., \& Björklund, L. (2013). Exploratory talk in science education: inquiry-based learning and communicative approach in primary school. Journal of Baltic Science Education, 12 (4), 482-496. ISSN 1648-3898

McCright, A. (2012). Enhancing students' scientific and quantitative literacies through an inquiry-based learning project on climate change. Journal of the Scholarship of Teaching and Learning, 12 (4), 86 - 102. ISSN-1527-9316

Milne, I. (2010). A sense of wonder, arising from aesthetic experiences, should be the starting point for inquiry in primary science. Science Education International, 21 (2), 102-115. ISSN-2077-2327

Mogias, A., Boubonari, T., Realdon, G., Previati, M., Mokos, M., Koulouri, P., \& Cheimonopoulou, M.T. (2019). Evaluating ocean literacy of elementary school students: preliminary results of a cross-cultural study in the Mediterranean region. Frontiers in Marine Science, 6: 396. doi: 10.3389/ fmars.2019.00396

Morrison, J. A. (2013). Exploring exemplary elementary teachers' conceptions and implementation of inquiry science. Journal of Science Teacher Education, 24, 573-588. doi: 10.1007/s10972-012-9302-3

Murphy, C., Varley, J., \& Veale, O. (2012). I'd rather they did experiments with us.... Than just talking: Irish children's views of primary school science. Research in Science Education, 42, 415-438. doi: 10.1007/s11165-010-9204-3

National Research Council (1996). National science education standards. Washington: National Academy Press.

National Research Council (2013). Next Generation Science Standards: For States, By States. Washington, DC: The National Academies Press. https://doi.org/10.17226/18290.

Namdar, B. (2018). Teaching global climate change to pre-service middle school teachers through inquiry activities. Research in Science \& Technological Education, 36 (4), 440-462. doi: 10.1080/02635143.2017.1420643

Osborne, J. \& Dillon, J. (2008). Science education in Europe: Critical reflections. King's College London: The Nuffield Foundation.

Ratinen, I., Viiri, J., \& Lehesvuori, S. (2013). Primary school student teachers' understanding of climate change: comparing the results given by concept maps and communication analysis. Research in Science Education, 43, 1801-1823. Doi:10.1007/s11165-012-9329-7

Reisner, M., \& Reed, S. (2011). SpongeBob - Uma aventura ecológica [Sponge Bob - An ecological adventure]. Sintra, Portugal: Evereste Editora.

Rickinson, M., Dillon, J., Teamey, K., Morris, M., Choi, M. Y., Sanders, D., \& Benefield, P. (2004). A review of Research on Outdoor Learning. National Foundation for Educational Research and King's College. London: Field Studies Council.

Rönnebeck, S., Bernholt, S., \& Ropohl, M. (2016). Searching for a 
common ground - A literature review of empirical research on scientific inquiry activities. Studies in Science Education, 52 (2), 161-197, doi: 10.1080/03057267.2016.120635

Santoro, F., Santin, S., Scowcroft, G., Fauville, G., \& Tuddenham, P. (2017). Ocean literacy for all. A toolkit. Paris: UNESCO.

Stefanelli-Silva, G., Pardo, J.C.F., Paixão, P., \& Costa T.M. (2019). University extension and informal education: useful tools for bottom-up ocean and coastal literacy of primary school children in Brazil. Frontiers in Marine Science, 6: 389. doi: 10.3389/fmars.2019.00389

Shymansky, J. A., Kyle, W. C., \& Alport, J. M. (2003). The effects of new science curricula on student performance. Journal of Research in Science Teaching, 40, (Supplement) S68-S85. doi:10.1002/tea.3660200504

UN (2015). Transforming our world: the 2030 agenda for sustainable development (A/RES/70/1). Author. Retrieved from https://sustainabledevelopment.un.org/content/documents/21252030\%20Agenda\%20for\%20Sustainable\%20 Development\%20web.pdf

Varma, K. (2014). Supporting scientific experimentation and reasoning in young elementary school students. Journal of Science Education and Technology, 23, 381-397. doi:10.1007/ s10956-013-9470-8 